\title{
RESEARCH ON THE DEVELOPMENT OF THE TRACTOR AND COMBINE FLEET IN LATVIA
}

\author{
Dainis VIESTURS, Ulbroka Research centre, Faculty Engineering, Latvia University of Agriculture, 1 Instituta Str., Ulbroka, Stopinu \\ distr., LV 2130, Latvia; viesturs uzc@apollo.lv (corresponding author) \\ Nikolajs KOPIKS, Ulbroka Research centre, Faculty Engineering, Latvia University of Agriculture, 1 Instituta Str., Ulbroka, Stopinu \\ distr., LV 2130, Latvia; uzc@ apollo.lv \\ Adolfs RUCINS, Ulbroka Research centre, Faculty Engineering, Latvia University of Agriculture, 1 Instituta Str., Ulbroka, Stopinu \\ distr., LV 2130, Latvia; arucins@1tk.lv
}

\begin{abstract}
The article offers an analysis of the development of the tractor and combine harvester fleet in $2001-2016$. There are stated tractors and combines of the most common brands registered in the country. A methodology has been developed for the estimation of an adequate quantity of tractors and combines for timely cultivation of the sowing areas under agricultural crops. The methodology is based on the calculation of the annual increase in the summary engine capacity of the entire fleet of tractors and combine harvesters, and its comparison with the annual increase in the sowing areas. It is assumed that $10 \%$ of the sowing areas are cultivated by worn-out tractors, and $7.5 \%$ of the new tractor and combine capacity is required for the replacement (amortisation) of the worn-out tractors. We consider that the increase in the summary capacity should compensate for the increase in the sowing areas, taking into account also the impact of the total yield upon the productivity of the machinery. It has been found out that during the period the summary engine capacity of the tractors has grown 1.52 times, the summary engine capacity of the combine harvesters -2.8 times; in the same period the area under agricultural crops has increased approximately 1.38 times but the area under cereals and canola - approximately 1.8 times. Several authors consider specific capacity $\mathrm{kWh}^{-1}$ as a criterion for the estimation of an adequate quantity of the machinery; therefore there are calculated also its changes in a 16-year period, with the specific capacity of both the tractors and combine harvesters increasing. The average specific power $\mathrm{kWh}^{-1}$ is considered as relatively high, but, due to the concentration of production, a decrease in this indicator is possible in the future. The average weighted capacity of the purchased new tractors and combine harvesters has also increased. The increase in the summary capacity of the tractor fleet compensates for the increase in the sowing areas and even exceeds it a little. In its turn, the increase in the summary capacity of the combine fleet allows timely harvesting the significantly increased sowing area, and more than twice the increased totals yield at the end of the period, and, compared to the beginning, slightly shorten the harvesting duration. The calculations do not include weather conditions during the harvesting period. As increase in the sowing areas and total yield is expected still further, upgrading of the tractor fleet should be continued at approximately the same rate - by purchasing, on the average, 600 to 700 new tractors and 80 to 100 new combine harvesters every year.
\end{abstract}

Keywords: fleet of tractors and grain combine harvesters, engine capacity, sown area

\section{INTRODUCTION}

The areas of agricultural lands in Latvia have been increasing every year, as well as the production of the products of the field and animal husbandry. For instance, in the period 2000-2016 the areas under cereals and canola have increased 1.8 times, the total yield - more than twice; the production of milk increased 1.3 times, the production of meat - 1.4 times (Materials of the Central Statistic Bureau ...). Such an increase was also promoted by the state subsidy policy (Public Report of the Ministry of Agriculture...). There is also growth in the production of the other agricultural products. Such production intensification requires also corresponding increase in the capacity of the fleet of tractors and combine harvesters as an important means of production. Data about the registered tractors and combines by their brands and models, data about the technical inspections of tractors and combines, as well as data about the tractors and combines purchased during a year by their brands and models have been registered every year by the State Technical Control Agency Several authors have conducted investigations about the age structure of the tractor fleet and its usage efficiency on the farms of various sizes (Kopiks N. et al., 2015, Olt J. et al., 2010, Barvicki J. et al., 2012.), however there are few investigations and data about the dynamics of the combine fleet (Pawlak et al., 2002), its use on the farms, as well as the adequate combine capacity for harvesting the growing areas under cereals. The purpose of the article is to estimate the updating progress of the fleet of tractors and combine harvesters, and its technical condition in the period 2000-2016, as well as to work out a methodology for the estimation of its capacity variations in this period, to characterise these variations in comparison with the growing amount of the sowing areas of agricultural crops and the amount of the product.

Copyright (C) 2017 The Authors. Published by Aleksandras Stulginskis University. This is an open-access article distributed under the terms of the Creative Commons Attribution License (CC-BY 4.0), which permits unrestricted use, distribution, and reproduction in any medium, provided the original author and source are credited. 


\section{MATERIALS AND METHODS}

The sales of tractors and combine harvesters made in Europe gradually started in Latvia since 1996, when state subsidies for agricultural production, including the purchase of machinery, were established. Trading in the machinery produced in the CIS countries had practically stopped by this time except the tractors made in Belarus. They, certified in accordance with the EU requirements, with the brand 'Belarus', are still purchased in Latvia in considerable amounts. However, intense updating of the tractor and combine fleet started after joining the EU in the year 2004 due to the availability of structural funds. Table 1 shows variations in the number of the most popular brands of tractors registered in Latvia in the period $2000-2016$.

As it is evident, the number of the new certified Belarus tractors that agree with the EU requirements, and the new tractors, made in the EU countries (John Deere, Valtra, the rest), is gradually increasing. The most popular (most purchased) tractors, made in the EU countries, are Valtra and John Deere. In the year 2016 their total number exceeded the number of the other tractors produced in the EU countries. The great number of the Belarus tractors is determined by the substantially lower price at the beginning of the period in contrast to the tractors produced in the EU countries, popularity of the brand and cheaper service possibilities; however, the purchase of these tractors is gradually decreasing. It can be assumed that all the tractors acquired since 2001 are in good technical condition and take part in the production of the product. In their turn, the number of the tractors made in the CIS countries (starting from position 5 in the table) has changed insignificantly (except K-700 and T-150K). The newest of these tractors have been in operation more than 20 years, and their contribution to the production of the product in the period mentioned is diminishing every year with age. Their number is very small in the last years although they are not excluded from the register. In good technical condition there is $33-34 \%$ of the total number of tractors, or $25-26$ thousand tractors.

Table 1. Variations in the number of the most popular brands of tractors registered in Latvia in the period 2001-2016.

\begin{tabular}{|c|c|c|c|c|c|}
\hline No. & Brand of the tractor & $\mathbf{2 0 0 1}$ & $\mathbf{2 0 0 5}$ & $\mathbf{2 0 1 0}$ & $\mathbf{2 0 1 6}$ \\
\hline 1 & Belarus & 708 & 2034 & 3001 & 4155 \\
\hline 2 & John Deere & 37 & 306 & 880 & 1587 \\
\hline 3 & Valtra & 98 & 487 & 1046 & 1537 \\
\hline 4 & The rest produced in the EU & 41 & 365 & 1109 & 2925 \\
\hline 5 & MTZ & 25265 & 25324 & 25449 & 25802 \\
\hline 6 & T-150K & 4098 & 3683 & 3494 & 3172 \\
\hline 7 & K-700 & 702 & 550 & 510 & 432 \\
\hline 8 & T-40 & 14619 & 14645 & 14696 & 14656 \\
\hline 9 & T-25 & 9981 & 9927 & 11105 & 11318 \\
\hline
\end{tabular}

A similar situation is with the fleet of combine harvesters - Table 2 shows variations in the number of the most popular brands of combine harvesters registered in Latvia in the period $2000-2016$.

Table 2. Variations in the number of the most popular brands of combine harvesters registered in Latvia in the period 2001-2016.

\begin{tabular}{|c|c|c|c|c|c|}
\hline No. & Brand of the combine harvester & $\mathbf{2 0 0 1}$ & $\mathbf{2 0 0 5}$ & $\mathbf{2 0 1 0}$ & $\mathbf{2 0 1 6}$ \\
\hline 1 & Claas & 108 & 323 & 476 & 722 \\
\hline 2 & John Deere & 37 & 127 & 212 & 303 \\
\hline 3 & New Holland & 17 & 89 & 162 & 286 \\
\hline 4 & The rest produced in the EU & 29 & 102 & 187 & 243 \\
\hline 5 & Niva SK-5 & 2208 & 1935 & 1852 & 1629 \\
\hline 6 & Jenisej1200 & 1116 & 1108 & 1106 & 1035 \\
\hline 7 & Don1500 & 197 & 185 & 179 & 170 \\
\hline
\end{tabular}

As it is evident from the data of the table, the number of the combine harvesters made in the European countries is gradually increasing; yet the quantity of the combines produced in the CIS countries, the newest of which have been in operation more than 20 years, has changed insignificantly (except NIVA SK-5). Most of the combine harvesters registered in Europe have been purchased as new, therefore they are in good technical condition, and one can assume that in the recent years they harvest absolutely the greatest part of areas under cereals and canola. In its turn, the contribution of the combine harvesters produced in the CIS countries to harvesting is decreasing every year during this period due to their aging, and lately it is very small, although they are not excluded from the register. This creates a situation that in the year 2016 the number of the registered combine harvesters exceeds 7500 but only $33 \%$ of them are good technical condition.

In order to evaluate the adequacy of the capacity of a tractor fleet for timely cultivation of agricultural land and adequacy of the capacity a combine fleet for timely cultivation of the sown areas, the following assumptions have been made:

- all the new tractors and combine harvesters purchased since 2001 are in an operating condition and they are running; their depreciation period is 15 years; their quantity and capacity by brands and models have been found out every year from the State Technical Control Agency's register; 
- knowing that in 2001 all of the sown area mentioned in the statistics was cultivated (harvested), the summary capacity of the new tractors purchased annually, as well as the summary capacity of the combine harvesters should ensure at least annual tillage (harvesting) and exceed it by $7-8 \%$ in order to cover the replacement of the machines worn-out in 15 years.

The data were obtained from (Reviews of the State Technical Control Agency 2001...2016.) about the number of the new tractors and combine harvesters purchased every year by their brands and models, and about their capacity; there was calculated the average weighted capacity of a unit of machinery of the respective brand, its summary capacity, as well as the summary capacity of the entire fleet of tractors, and the summary capacity of the fleet of combine harvesters. The said summary capacity has been reduced by $7.5 \%$ in order to ensure depreciation of the 15 years' old combine harvesters but increased by $10 \%$, which could approximate characterise the working capacity of the old machines from the CIS countries and the used machines purchased from other countries abroad. The increase in the summary capacity should be at least equivalent to the increase of the sowing areas. Knowing the summary capacity and the sowing area, it is also possible to analyse variations in the specific capacity. As several authors remark (Olt J. et al., 2010, Pawlak J. et al., 2002) the specific capacity of tractors kW.ha ${ }^{-1}$, can be an indicator for the estimation of an adequate quantity of tractors for timely and qualitative execution of the field work. The methodology was prepared using an approach outlined in the previous publications (Viesturs D, Kopiks N., 2016, Viesturs D, Kopiks N., 2017) by the authors.

\section{RESULTS AND DISCUSSION}

The working capacity of a fleet of machines is characterised by their summary capacity. As mentioned in the previous chapter, for the tractors, this indicator is to be viewed together with the entire area under all agricultural crops in respective year, but for the combine harvesters, - together with the area under cereals and canola. Variations in the summary capacity of the tractor fleet and areas under agricultural crops in every five years are shown in Figure 1.

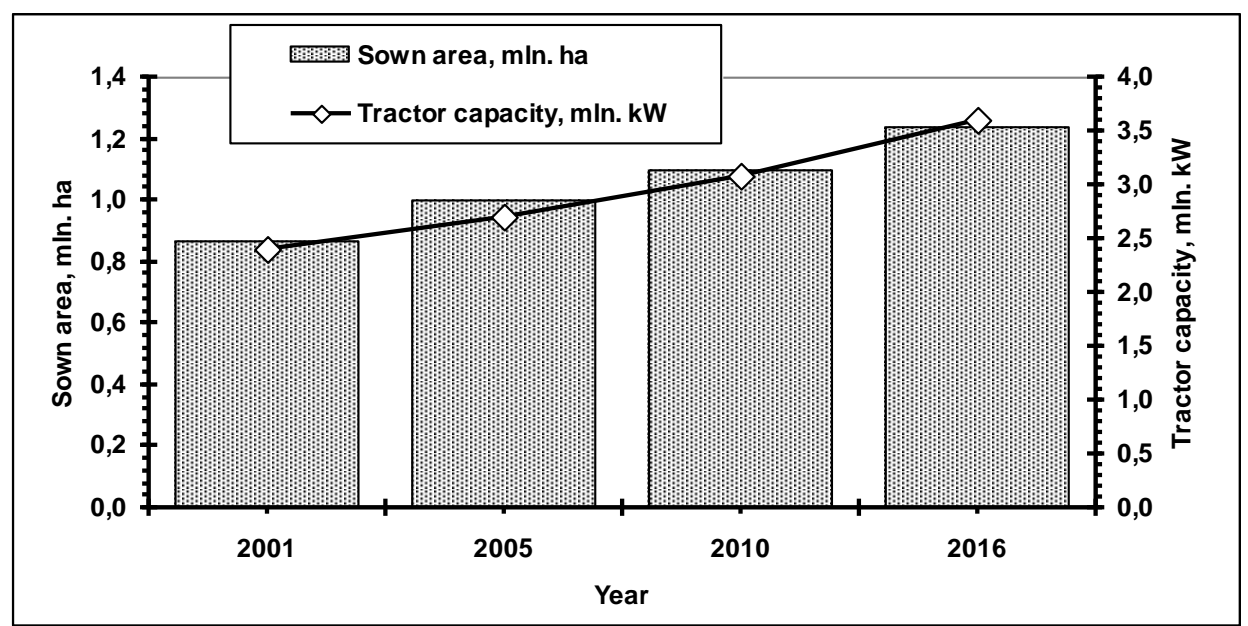

Figure 1. Variations in the summary capacity of the tractor fleet and areas under agricultural crops in 2001-2016.

During the period discussed the sown area has increased 1.38 times while the summary capacity of the fleet of tractors - 1.52 times. Pre-emptive capacity increase allows execution of operations in shorter agrotechnical terms, as well as provides a possibility to renew the outdated tractor fleet. However, when evaluating these indicators, it should be taken into account that during this period the production of crops has considerably increased, for instance, growing cereals and canola has almost doubled.

Along with the summary capacity as an indicator that characterises the energy supply of agriculture, several authors (Kopiks N. et al., 2015, Pawlak J. et al., 2002) recognize the specific capacity obtained by dividing the summary capacity by the sown area of agricultural crops in a respective year. According to the analysis of the Central Statistic Bureau survey data, this indicator in Latvia, depending on the size and type of farms producing goods, ranges from 1.30 to $4.10 \mathrm{~kW}$.ha${ }^{1}$ (Kopiks N. et al., 2015), whereas according to the (Pawlak J. et al., 2002) data, this indicator in the European countries, depending on the size of the farms, was $1.06-8.10 \mathrm{~kW} \cdot \mathrm{ha}^{-1}$. Variations in the specific capacity of tractors and the average capacity of a new tractor over a period of 16 years in Latvia are shown in Figure 2.

As it is evident, the specific capacity has grown from 2.68 to $3.21 \mathrm{~kW} . \mathrm{ha}^{-1}$, or 1.20 times. Such an increase is connected both with the increased number of the new tractors (particularly intense it was in 2011-2013), and the increased average weighted capacity of a new tractor. During 16 years this capacity has grown from 66.10 to $99.82 \mathrm{~kW}$, or 1.51 times. This increase in the average capacity of the tractor can be evaluated as small, considering entrance into Latvia of the brands of tractors made in the EU countries. The small increase in the average capacity is connected with a substantial ratio of the Belarus tractors - from the new 10148 tractors purchased during 16 years 4166 , or approximately $40 \%$ are of the Belarus brand. However, the average weighted power of the new tractors of this brand has grown during 16 years only 
from $63.51 \mathrm{~kW}$ to $72.09 \mathrm{~kW}$, or 1.13 times. Yet it should be noted that the annual purchase of the tractors of the Belarus brand is decreasing - in the year 2000 there were $88 \%$ of the new tractors, in the year $2005-52 \%$, in the year $2010-$

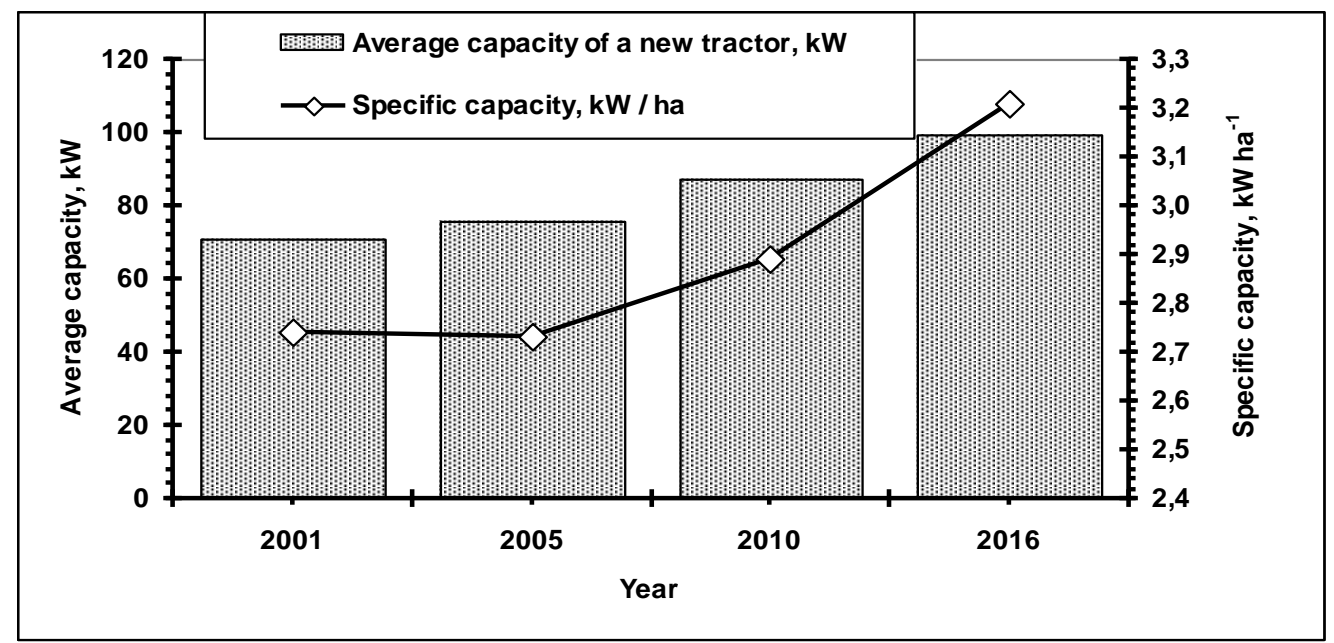

$28 \%$; in the last years stabilising within the range of $28-30 \%$.

Figure 2. Variations in the specific capacity of tractors and the average weighted capacity of a new tractor in 2001-2016.

In its turn, Figure 3 shows the summary capacities of the combine engines, as well as the variations in the total area under cereals and canola.

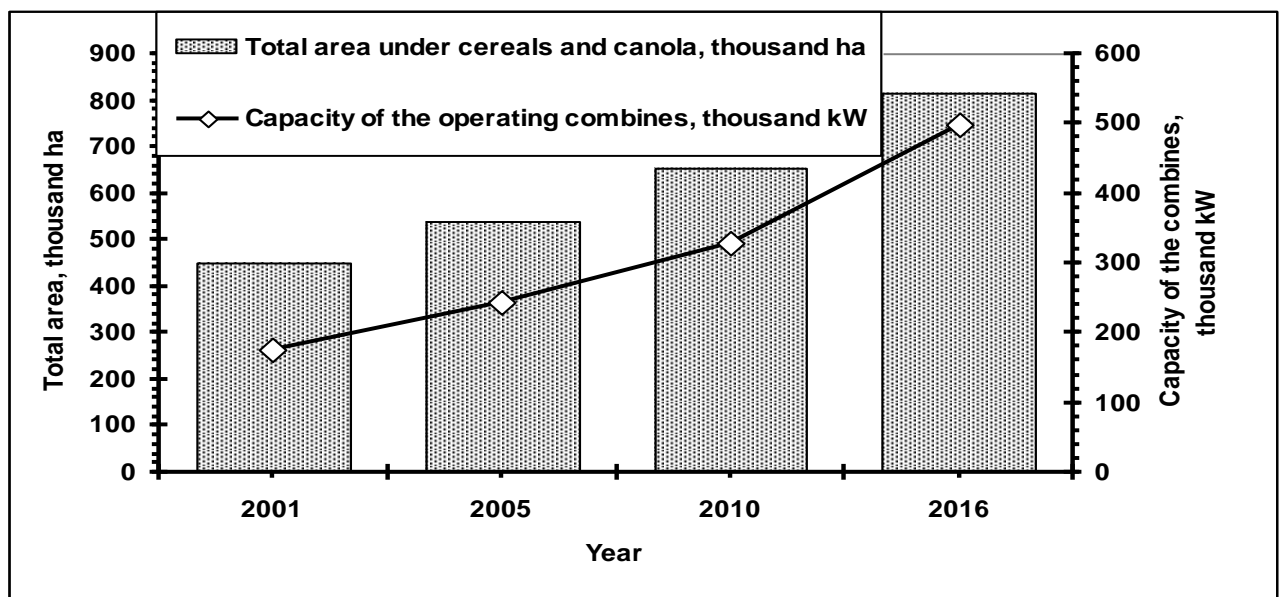

Figure 3. Summary capacities of the engines of the combine fleet, as well as variations in the total area under cereals and canola in 2001-2016.

In the period the area under cereals and rape has increased from 452.1 to 816.1 thousand ha, or about 1.8 times, while the summary engine capacity of the operating combine harvesters has increased from 175.8 to 498.7 thousand $\mathrm{kW}$, or 2.8 times. This indicates a significant increase in the summary capacity of the combine harvesters and, consequently, a possible increase in productivity as compared to the increase in the sowing areas. Thus, if assessing by these indicators, the duration of harvesting at the end of the period should become shorter. Yet it is important that the yield has increased, as well as the total yield of cereals and canola - in the period from 2001 to 2005 it averaged 1118.9 thousand tons, but in the period from 2012 to 2016 the yield was 2691.8 thousand tons a year - the total yield had increased more than twice. Such an increase in the amount of the harvested grain, in its turn, reduces the potential productivity of the fleet of combine harvesters by about 1.5 times (Клочков А.В., 2010).

Variations in the specific capacity of combine harvesters and the average capacity of a new combine in a 16 years' period are shown in Figure 4. As can be seen, the specific capacity has increased from 0.39 to $0.66 \mathrm{~kW} . \mathrm{ha}^{-1}$, or about 1.7 times. Such increase in the capacity cannot be explained only by the increased quantity of the new purchased combines; their number is growing in the last seven years, in contrast to the beginning of the period, slightly more intensely; however, in the long run it is relatively stable - on the average, 96 combine harvesters are bought a year. The significant increase in the specific capacity during the period is explained by the variations in the average weighted engine capacity of one new combine purchased in 2001-2016 as shown in Figure 4. During 16 years this capacity has increased from 212.0 to $366.1 \mathrm{~kW}$, or 1.7 times, i.e. in 2016 the average capacity of the newly acquired combine harvester engines has been $358.2 \mathrm{~kW}$. The increase in the average engine capacity of a newly acquired combine and the increase in its specific capacity are almost proportional. Thus, the analysis of the energy supply allows expressing an optimistic forecast about the possibilities of timely harvesting of the yield. 


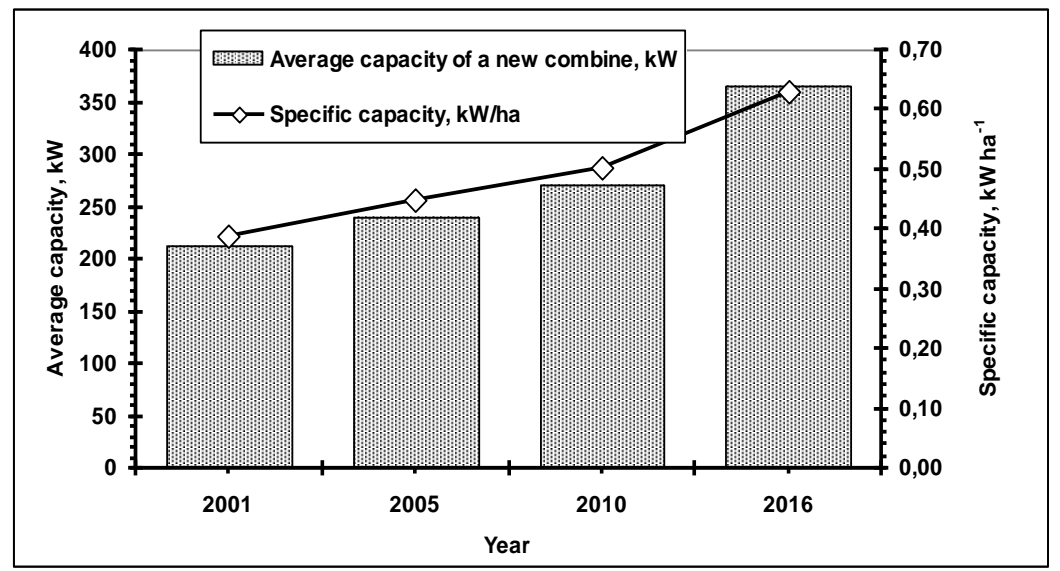

Figure 4. Variations in the specific capacity of a fleet of combine harvesters and the average weighted capacity of a new combine in 2001-2016.

When estimating the adequacy of the summary capacity of the tractor and combine fleet for the cultivation of the increasing areas under agricultural crops and the total yield, one can find that the increase in these capacities compensates for the increase in the areas and the total yield, slightly pre-empting it, which allows execution of the operations in shorter agrotechnical terms. The registration procedure of tractors and combine harvesters existing in the country allows being of a large number of outdated and worn-out machines in the register, as a result of which, despite annual purchases of new tractors, the average age of the fleet increases. However, the production of goods for the market takes place by means of highly productive, modern machines while the worn-out machinery performs a little amount of work on the backyard farms. The value of the average specific capacity should be regarded as relatively high because, as stated in the previous studies [3], the specific capacity on the farms over 100 hectares is significantly lower. As the increase in the sown areas is expected to continue still further, upgrading of the machine fleet should be continued at approximately the present rate, with an average purchase of 600-700 new tractors and 80-100 new combine harvesters year.

\section{CONCLUSIONS}

1. In the recent years in a good technical condition there are only 33-34\% of the entire number of the registered tractors and combine harvesters; however, the production of goods for the market takes place by means of modern machines.

2. The increase in the summary capacity of the tractor and combine fleet during the last 15 years compensates for the increase in the sown area and the total yield during this period, which allows timely execution of the fieldwork.

3. Due to the concentration of production on larger farms, the average capacity of new tractors and combine harvesters will continue to grow, but the average specific capacity, or the energy supply kW.ha ${ }^{-1}$, might decrease.

4. As the increase in the sown areas is expected to continue further, upgrading of the machine fleet should be continued at approximately the present rate, with an average purchase of 600-700 new tractors and 80-100 new combine harvesters a year.

\section{REFERENCES}

1. Barvicki, J, Gach, S, Ivanovs, S. 2012. Proper utilization of soil structure for crops today and conservation for future generations. Proceedings of $11^{\text {th }}$ International Scientific Conference "Engineering for Rural Development", Vol. 11, pp. 10-15, Latvia University of Agriculture.

2. Kopiks, N, Viesturs, D, Valainis, O. 2015. The Fleet of Tractors on the Farms of Latvia, its Structure and Energy Intensity. Proceedings of $14^{\text {th }}$ International Scientific Conference "Engineering for Rural Development", pp.84-87.

3. LR Centrālās statistikas pārvaldes materiāli 2001. 2016.g., datubāze "Lauksaimniecība, mežsaimniecība un zivsaimniecība". (Materials of the Central Statistic Bureau of Latvia 2001...2016). [In Latvian].

4. Olt, J., Traat, U., Kuut, A. 2010. Maintenance Costs of Intensively Used Self-Propelled Machines in Agricultural Companies. Proceedings of $9^{\text {th }}$ International Scientific Conference "Engineering for Rural Development", pp.42-48, Latvia University of Agriculture.

5. Pawlak, J, Pelizzi, G., Fiala M. 2002. On the Development of Agricultural Mechanization to Ensure a Long-Term World Food Supply. Journal of Scientific Research and Development, Vol. IV, pp. 1-15.

6. Valsts Tehniskās uzraudzības aǵentūras pārskati 2001...2016.g. (Reviews of the State Technical Control Agency 2001...2016). [In Latvian].

7. Viesturs, D, Kopiks, N. 2016. Investigations in Suitability of Fleet of Combines for timely Harvesting. Proceedings of $15^{\text {th }}$ International Scientific Conference "Engineering for Rural Development", Vol. 15, pp. 681-686, Latvia University of Agriculture. https://doi.org/10.22616/ERDev2017.16.N106

8. Viesturs, D, Kopiks, N. 2017. Trends in Development of Tractor Fleet in Latvia. Proceedings of 16 ${ }^{\text {th }}$ International Scientific Conference "Engineering for Rural Development", Vol. 16, pp. 534-539, Latvia University of Agriculture. 
9. Zemkopības ministrijas Publiskais pārskats 2001....2016.g. Rīga, Zemkopības ministrija. (Public Report of the Ministry of Agriculture 2001...2016) [In Latvian].

10. Клочков, А.В. 2010. Обоснование состава парка зерноуборочных комбайнов в Республике. (Substantion of the Composition of the Fleet of Combine Harvesters). Весиі Нацыянальнай акадэміі навук Беларусі, №. 4, cmp.114-119. [In Russian]. 